\title{
Energy performance improvement and cultural enhancement of the Andalusian rural heritage: case study - "El Cortijo del Fraile"
}

\author{
M. I. Pérez Millán, R. T. Yáñez Pacios, A. Contreras García \\ \& A. Socorro Picó \\ University of Alicante, Spain
}

\begin{abstract}
The renovation of old cortijos, haciendas or lagares is a topical subject within the context of enhancing the Andalusian agrarian architecture. The abandonment of these unique farmhouses structures due to the industrialisation of the harvesting process has already drawn the administration's attention to the importance of encouraging its maintenance. The Public Works and Housing Office and the Culture Office of the Andalusian Government, as well as local administrative bodies, have promoted its identification, examination and analysis to manage rehabilitation policies that facilitate the adaptation of these spaces of architectural heritage to new uses. This research paper gathers the methodology for the energy renovation of these constructions, enhancing their characteristic infrastructures and most significant assets. Various strategies support the traditional existing facilities of the "cortijos" inserting new technologies to supply the needs of the new programmes, optimizing the existing resources. Increasing rainwater collection surfaces and storage; improving the filtering and recycling methods to recycle rainwater, grey water and sewage; and increasing the effectiveness of solar and wind energy collection with new technologies that complement the old passive knowledge with updated designs or active systems. The main goal of this paper is to find strategies to extrapolate its application in similar cases among the Mediterranean European context. The application of this methodology in a case study shows the energy performance improvements proposed for the "Cortijo del Fraile", located on the southeast of Nijar (Almería), inside the Natural Park of "Cabo de Gata-Nijar".
\end{abstract}

Keywords: Andalusian rural heritage, cultural rehabilitation, architectural rehabilitation, bioclimatic strategies. 


\section{Introduction}

The constructions known as "cortijos" (country properties) refer to a type of dispersed rural habitat pertinent to agricultural holdings belonging to big landowners [1]. They are characterised as constructions which include both living areas and annexes necessary for the farming business, and although the term makes specific reference to the type that is typical of Western Andalusia, it is extended to similar forms of housing in other parts of Spain. We also find similar farm constructions in areas of Europe such as those known as cascinas a corte, corte colonica, case di corte or corte lombarda in Italy [2].

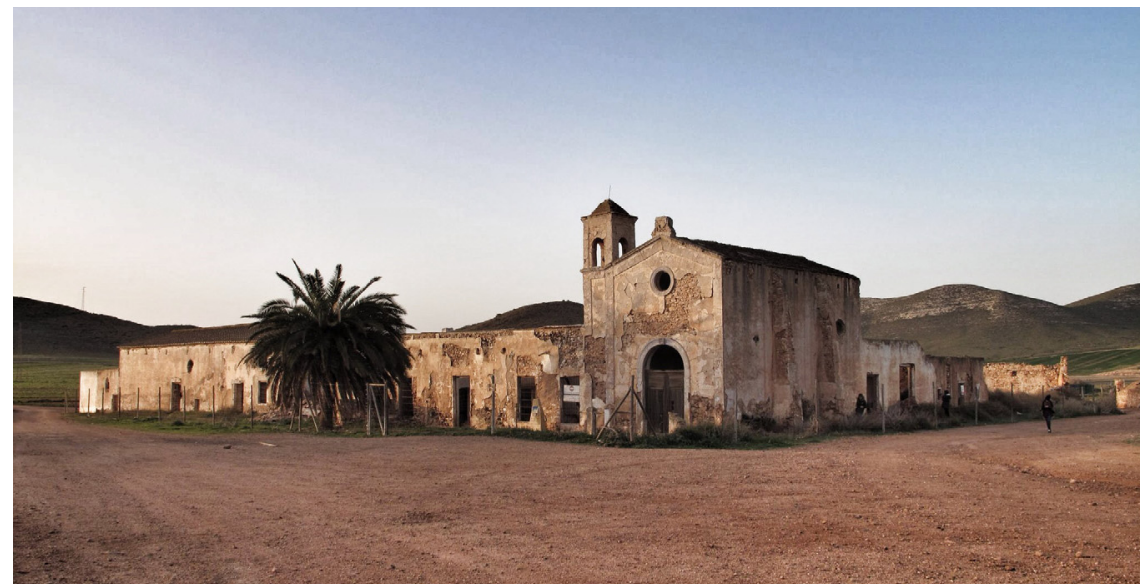

Figure 1: Present condition of the Cortijo del Fraile (2015) (photo by the authors).

The historical importance of farming in Andalusia converts these agricultural constructions into essential elements of its territorial organisation, becoming the basis of human settlements in this region. As they are elements of architectural heritage isolated in agricultural landscapes, they are visual landmarks that have characterised the landscape since before the 18th century but especially since the increase of this type of construction during the 19th century. Their distribution and physiognomy reflects the methods of production, ownership patterns, and other aspects relating to farming and associated economic production. This is what makes them ethnologically interesting, as they are orientated primarily to being functional, where their general morphological features, constructive resources and patterns of internal organisation mark the different architectural tendencies of the different areas and eras [3].

But a number of factors have altered this productive system. On the one hand because of advances in agriculture, with the systematisation of the growing and harvesting processes and the introduction of agricultural technology and machinery, structures of this type of are no longer essential. On the other hand, 
the economic policies of the country have guided its interests towards the services sector, distancing it from the primary and secondary sectors.

The population movements from rural areas to towns have made farm structures obsolete and in many cases they are left abandoned, leaving some of these buildings in ruins. In some cases, they are recuperated through a change of use which means they continue to be present in our historical heritage. This is why their vernacular architecture of construction materials and methods typical of the area need to be adapted to the requirements imposed both for their new use and under current legislation. Preserving their identity as an ethnological and cultural legacy of this type of rural settlement is just as important as evaluating them from an energy aspect in order to consider including compatible technologies in their renovation that will allow them to be efficient and independent at consumer level.

\section{State of the art}

Of the publications written about reutilising buildings in our rural heritage, some of them are more focussed on practical examples that make use of the methods proposed [4-6], where they catalogue and inventory buildings of interest for subsequent rehabilitation. Those that are focussed on the practical application of energy-based rehabilitation techniques usually have a conservative approach because they are centred on buildings which are monuments, particularly on buildings in use for which the cost and the needs are known [7]. But some, like in our case, undertake the restoration of buildings of different origin in order to give them a new activity with which to recover their use, for example former religious [8], industrial [9-11] or commercial buildings [12] or rural constructions, such as in our case $[13,14]$. The vernacular architecture developed bioclimatic concepts which were applied instinctively in their constructions and nowadays are still perfectly valid.

\section{Strategies}

The general guidelines lean toward the modernisation of the building by involving systems for obtaining or producing clean energy from the sun, wind, water or ground [13]. They propose a number of strategies through which the agricultural buildings mentioned can be rehabilitated to different degrees. These are classified in accordance with their primary function: climate control, generating power, water supply and cultural rehabilitation. A work method is developed for each of them based on the objectives that are hoped to be achieved in an attempt to optimise the existing resources and improve the comfort of the user in the building. The results of the strategies are shown in the proposal for the architectural rehabilitation of country properties, analysing the different parts of the actions to be taken. 


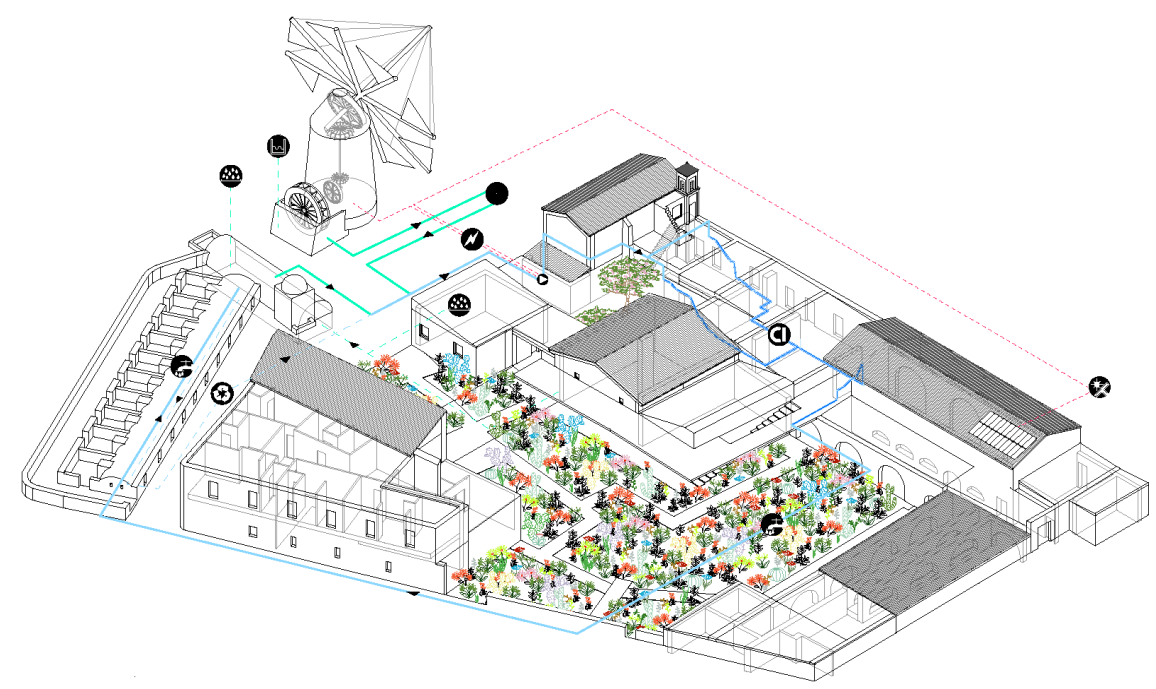

Figure 2: Project for action to be taken in the Cortijo del Fraile for renovating the building using the bioclimatic strategies put forward by the authors. Diagram by the authors.

\subsection{Climate control strategies}

Although the Mediterranean climate in the province of Almeria is very varied, the low latitudes and almost desert-like conditions of the Cabo de Gata define it as infra-Mediterranean. This bioclimatic level can be found in the Iberian Pensinsula in a very narrow strip of the south-eastern coast where the influence of the sea prevents winter frosts. Rainfall is low, this being the place where there is less rain in the whole of the Iberian Pensinsula. In these conditions, the strategies for climate control focus on cooling both interiors and the exterior areas around the building.

\subsubsection{Exterior cooling}

In order to bring down the temperature of exterior spaces, methods are used based on the phenomenon of evaporative cooling [14]. The air brings the heat necessary for evaporating the water until the air is saturated with moisture and, as the level of moisture generated would be incompatible with the user's comfort, it is only used in exteriors.

This type of passive cooling is used in areas such as gardens, where cooling elements include water as a basic feature (for example fountains or ponds). The same effect is achieved with the "clay pot effect" but on a more sophisticated scale. The water diffuses through the pores of the clay and evaporates when it comes into contact with the exterior atmosphere, causing the cooling action.

In the case study, the proposal for applying this strategy is based on a system developed by the Institute of Advanced Architecture in Catalonia [15]. By applying hydrogel introduced into ceramic as the supporting material and cloth 
as a membrane, the walls are made to "sweat", reducing the temperature by up to 5 or 6 degrees centigrade, depending on the outside temperature.

By placing this type of structure on the walls of patios and at the entrance to the country house, the atmosphere of those areas can be cooled down.

\subsubsection{Interior cooling}

Considering that the free height of interior spaces is limited, a water-based radiant system is used which works by running through sections of capillary tubes behind walls and ceiling. Water carries a higher amount of energy than air, providing a more efficient cooling system which requires less space. A supplementary forced ventilation system would be necessary as this system does not use fans for heating or cooling the rooms.

The location of the Cortijo del Fraile lies within one of the most important hydro-geological units in the area [16]. Groundwater is present all year round at a constant temperature range of $18-21{ }^{\circ} \mathrm{C}$, and this natural temperature of the subsoil can be used as a heat source or a heat dump. The cooling wells exchange heat energy for cooling the interior of the buildings [17]. The use of this system could result in an increase in groundwater temperature, which would have a serious effect on the aquifer network. Hendriks and Godschalk [18] proposed using an Aquifer Thermal Energy Storage (ATES) system to dissipate the thermal energy transferred to water during the summer by storing it in an additional well and subsequently using it for heating in winter, thus reducing this effect. This whole system would be backed up by external heat pump connected to the main circuit to guarantee a suitable interior temperature with the lowest energy consumption possible.

\subsection{Energy-obtaining strategies}

In order for the system to be self-sufficient in energy, a number of strategies are considered that will make it possible to obtain and store energy by making use of the natural conditions of the area, as traditionally was done in the past, or the use of new technologies to optimise them.

\subsubsection{Water power}

In this geographical area, considered to be a socialised space, there are various examples whose unifying factor is based on the different ways of collecting, storing and distributing water. Amongst these, depending on the hydraulic context, water mills are worthy of mention, due to their large number and diversity. Also known as a "rodezno" mill or flour mill, this system of obtaining energy consists of two elements: the noria and the horizontal water wheel (the "rodezno").

To be applicable in this project, the noria activated by the windmill would collect the water and carry it to a channel from where it will circulate by gravity until it enters the interpretation centre. The water not collected by the noria continues down the channel, coming out by the headrace with sufficient force to activate the horizontal water wheel or driving wheel and move the millstones. This generates the electrical power necessary for pumping the water which will 
follow the same circuit - or removing it directly through the cavity if there is too much. This way, the constant water circulation works without needing any external power source.

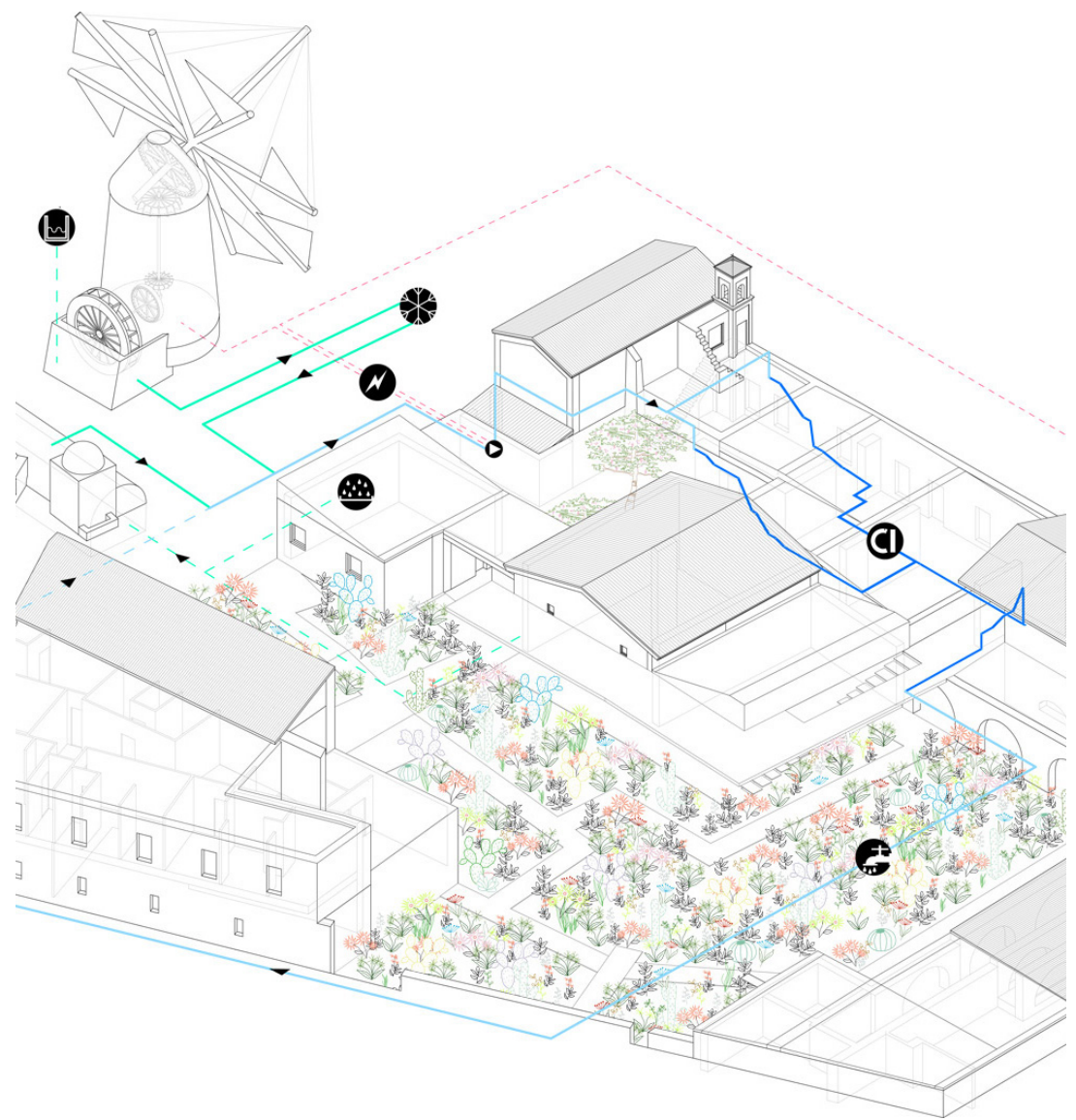

Figure 3: Detail of the proposed action in the Cortijo del Fraile for renovating the building by obtaining power from natural sources. Diagram by the authors.

\subsubsection{Wind power}

The heritage of cisterns, water tanks, mills and waterwheels in Cabo de Gata displays the great values of their function, morphology, type and symbolism in the area. In the case of the Almerian windmill, this differs from the so-called Andalusian mill, which is present in other parts of the region, and is closer in type to the mills in La Mancha, which makes it more distinctive. Within the scope of the Cabo de Gata Natural Park a group of these devices has been restored in recent years. The Cortijo del Fraile did not originally have one in its architectural ensemble, but the intention is to build one following the models 
existing in the area, reviving it as a cultural element, in addition to obtaining extra power from a traditional sustainable source.

Table 1: Wind historical data in Cabo de Gata-Níjar. Source: Agencia Estatal de Meteorología AEMet (Spanish Meteorological Agency).

\begin{tabular}{|l|c|c|c|c|c|}
\hline \multicolumn{1}{|c|}{ Season } & Winter & Spring & Summer & Autumn & Year \\
\hline Prevailing wind direction & N-O & N-O & N-O & N-O & N-O \\
\hline Wind probability $(\%)$ & 30 & 29 & 32 & 31 & 32 \\
\hline Wind speed $(\mathrm{km} / \mathrm{h})$ & 29 & 20 & 20 & 19 & 19 \\
\hline Air temperature $\left({ }^{\circ} \mathrm{C}\right)$ & 19 & 16 & 24 & 25 & 20 \\
\hline
\end{tabular}

\subsubsection{Solar power}

As an essential backup method of obtaining energy, solar power is proposed for obtaining electricity from photovoltaic panels. Of the different technologies and uses, this is the one that is best suited to the case study, as its geographical features provide solar radiation of $1900 \mathrm{kWh} / \mathrm{m}^{2}$ [19].

With this facility, in which the solar panels will be placed on top of the sloping roof of the country house, the energy supply for the case study is guaranteed. Due to its orientation, two separate sections are designed to capture solar energy at two different times of day, depending on the angle of the sun, in order to optimise the amount of energy captured.

Table 2: Programme of proposed uses and consumption requirements anticipated.

\begin{tabular}{|c|c|c|c|c|c|}
\hline Programme & Residential & Classroom & Museum & Restaurant & Offices \\
\hline Requirement & $14,000 \mathrm{~W}$ & $250 \mathrm{~W}$ & $500 \mathrm{~W}$ & $500 \mathrm{~W}$ & $50 \mathrm{~W}$ \\
\hline
\end{tabular}

Table 3: Calculations and checks made with the REBT CYPELEC program considering coefficients of simultaneity.

\begin{tabular}{|l|c|c|}
\hline Results & Number & Power/storage \\
\hline Panels & 28 & $400 \mathrm{~W}$ \\
\hline Accumulators & 2 & $850 \mathrm{Ah}$ \\
\hline
\end{tabular}

\subsection{Water supply}

Due to the arid nature of the climate in the area, water is a rare commodity, although during the year there are large quantities of rainfall at certain times.

One of the solutions for combating the lack of water is by making efficient use of rainwater, which is supplemented by the storage systems already existing 
in the complex, the water storage tanks. These traditional tanks will store the rainwater collected from the built-up parts of the land. This system connects to the main water circuit, providing the necessary additional amount that is needed without having to spend money on the general water supply.

Table 4: Average total precipitation in mm (1981-2010). Source: Agencia Estatal de Meteorología AEMet (Spanish Meteorological Agency).

\begin{tabular}{|c|c|c|c|c|c|c|c|c|c|c|c|c|}
\hline Jan & Feb & Mar & Apr & May & Jun & Jul & Aug & Sep & Oct & Nov & Dec & Year \\
\hline 23.6 & 25.1 & 16.2 & 16.9 & 12.3 & 5 & 1.1 & 0.6 & 13.9 & 26.7 & 28.4 & 30.1 & 199.9 \\
\hline
\end{tabular}

Table 5: Quantification of the rainwater tanks and usage needs of rainwater.

\begin{tabular}{|c|c|c|c|c|c|}
\hline \multicolumn{6}{|c|}{ Annual Recovered Rainwater (ARR) } \\
\hline \multicolumn{2}{|l|}{ Surfaces A } & $\mathbf{e}$ & Ae $_{\mathrm{ff}}$ & $\mathbf{H}_{\mathbf{a}}$ & nf \\
\hline Footbridges & $626 \mathrm{~m}^{2}$ & $0.8 \%$ & $501 \mathrm{~m}^{2}$ & \multirow{3}{*}{ (Table 4) } & \multirow{3}{*}{ Reference [20] } \\
\hline New roofs & $627 \mathrm{~m}^{2}$ & $0.8 \%$ & $502 \mathrm{~m}^{2}$ & & \\
\hline $\begin{array}{l}\text { Existing } \\
\text { roofs }\end{array}$ & $587 \mathrm{~m}^{2}$ & $0.8 \%$ & $470 \mathrm{~m}^{2}$ & & \\
\hline & & & $\Sigma 1473 \mathrm{~m}^{2}$ & $2041 / \mathrm{m}^{2}$ & 0.9 \\
\hline \multicolumn{6}{|c|}{ Annual efficiency of rainwater $=\Sigma$ Aeff $\times$ Ha $\times \eta f=\mathbf{A R} \mathbf{R}=\mathbf{2 7 0 . 3 4 3}$ litres } \\
\hline \multicolumn{6}{|c|}{ Annual Rainwater Demand (ARD) } \\
\hline Type of use & & $\mathbf{N}_{\mathbf{d}}$ & $\mathbf{N}_{\mathbf{p}}$ & $\mathbf{U}$ & ND \\
\hline Bathroom & & $451 / p$ & $501 \mathrm{~m}^{2}$ & 365 & $98.5501 /$ year \\
\hline Other uses & & $61 / p$ & $502 \mathrm{~m}^{2}$ & 287 & $17.2011 /$ year \\
\hline Vernacular $\mathrm{xe}$ & iscape & $853 \mathrm{~m}^{2}$ & $470 \mathrm{~m}^{2}$ & 6.5 & $166.2961 /$ year \\
\hline \multicolumn{6}{|c|}{ Annual water demand for services $\Sigma$ ND $=\mathbf{A R D}=\mathbf{2 8 2 . 0 4 6} 1 /$ year } \\
\hline \multicolumn{6}{|c|}{ Tank net volume $V_{u}=\left(A R R+F_{s}[5 \%]\right) \times C_{D}=45.134 \mathrm{l}$} \\
\hline
\end{tabular}

\subsection{Cultural restoration}

Under the strategy of cultural restoration, new functions related to the context and architectural heritage are assigned to the complex for attracting users and so that the activities carried out in it not only encourage an indirect conservation of the building but also provide an added cultural attraction to the area where it is implemented [21].

In recent decades this type of strategy has been very habitual for re-utilising industrial buildings that have fallen into disuse, as these large, abandoned spaces can house a wide variety of cultural programmes. There are examples of this all round the world [22] 
Similarly, action has been taken with the rural heritage, but most of these are related to the services sector. These are usually cases where the building recovers its use by being adapted to holiday accommodation, and in some cases even coming under UNESCO protection [23]. We have already put forward the use of country properties and manor houses in the province of Almeria [24] and other parts of Andalusia [25], analysing both the tourism and environmental aspects, with the aim of proposing it as a sustainable solution.

The following table shows the total number of rural historical heritage buildings in Andalusia and how many of those are classified as country properties in the region. Out of this figure of country properties according to provinces, 190 are dated within the period between the 16th and 20th centuries, and specifically for the province of Almeria, there are currently 25 country properties dating from the 18 th century.

Table 6: Compilation by the authors of the haciendas, lagares and cortijos catalogued in Andalusia. Source: http://www.iaph.es/cortijoshaciendas-lagares-andalucia/frmSimple.do

\begin{tabular}{|ccc|}
\hline Andalucía & Total & Cortijos \\
Almería & 104 & 100 \\
\hline Cádiz & 186 & 132 \\
\hline Córdoba & 206 & 120 \\
\hline Granada & 159 & 122 \\
\hline Huelva & 0 & 0 \\
\hline Jaen & 0 & 0 \\
\hline Malaga & 136 & 107 \\
\hline Sevilla & 149 & 52 \\
total & $\mathbf{9 4 0}$ & $\mathbf{6 3 3}$ \\
\hline
\end{tabular}

\begin{tabular}{|cccc|}
\hline $\begin{array}{c}\text { Century } \\
\text { 13th }\end{array}$ & Total & Cortijos & Almería \\
\hline 14th & 2 & 0 & 0 \\
\hline 15th & 0 & 0 & 0 \\
\hline 16th & 10 & 6 & 0 \\
\hline 17th & 4 & 1 & 0 \\
\hline 18th & 65 & 38 & 4 \\
\hline 19th & 146 & 83 & 16 \\
\hline 20th & 93 & 62 & 5 \\
\hline total & $\mathbf{3 2 0}$ & $\mathbf{1 9 0}$ & $\mathbf{2 5}$ \\
\hline
\end{tabular}

The Cortijo del Fraile, one of the four 18th century Cultural Heritage Buildings (BIC for its initials in Spanish) located in Almeria, was built by the Dominican friars and passed into private hands in the mid-19th century.

The "Fraile" is the best example of a large country property erected under planned construction to serve a large community. Its lines and structure display a combination of the arrangement of a long-standing urban composition and style pertaining to the probable time of its construction and the local resources and solutions for buildings which would respond to the requirements of a traditional agricultural and livestock operation. After losing its original use, it fell into a state of neglect in the second half of the 20th century XX, characterised by a period in which the services sector had precedence over farming and leading to migrations from rural areas to towns. The lack of conservation and maintenance has left this cultural heritage building in a state of ruin and complete neglect.

The proposed action in this case study began in 2014 following a contest for ideas for revitalising its cultural, ethnological and landscape value. The proposal is to restore this Cultural Heritage Building by giving it a new use which will 
include an interpretation centre for the Cabo de Gata-Nijar area and a programme related to fruit and vegetable research that will include accommodation for the researchers. At the same time, workers and visitors are incorporated into the new programme, ensuring that both the constructive heritage and the environment will be maintained and preserved [26].

This way, this restored heritage building could be included within the cultural network of the Cabo de Gata-Níjar natural park, where there are currently 7 points providing an information service under the Regional Government of Andalusia: Isleta del Moro, La Amatista, Las Amoladeras, Las Sirenas, Los Muertos, Noria del Pozo de los Frailes, Rodalquilar. Apart from these information points, where visitors are offered activities, places of interest, and literature, there are also nature classrooms.

\section{Conclusions}

The disappearance of an activity gives rise to serious problems for the survival of its heritage. In this case, the disappearance of the agricultural activity creates problems for the rural heritage. At present there are many buildings within our cultural heritage that are in a state of neglect due to disuse and lack of maintenance.

The historic memory of the forms of economic activity of the past cannot be lost, because there are historical, cultural and educational reasons for conserving rural buildings. The buildings and the material components of this activity are our best reference to them. We have to conserve buildings that are a reference to now obsolete production processes and that might have disappeared. It is important to maintain diversity in the landscape of built heritage. In the words of Capel Saez [10] "Efforts must be made to maintain the diversity of built heritage (...) in order to conserve the diversity and heterogeneity of urban [rural] space".

The architectural and technical interest in the rural heritage and its social, ethnological and historic value inspire the need to restore it, but this involves the financial and technical feasibility, not only of restoration but also of its maintenance and subsequent use. The policies for protecting these buildings involve self-subsistence, not continuous public funding. By introducing activities which not only give them a use but also incorporate them into a cultural network, the self-financing and upkeep of the building would be made possible.

For this to happen, the buildings need to be properly conditioned and have facilities that allow for the comfort of their users. Through rehabilitation strategies that adapt the building to the new requirements for its use, it can be self-sufficient in energy, minimising consumption by obtaining energy from natural sources and re-utilising the traditional hydraulic and wind power systems characteristic of this type of power source. 


\section{References}

[1] García Baquero, G. Geografia Física y Humana de Andalucía: La población, factores del pasado, Ed. Síntesis, Madrid, p. 163, 1990.

[2] Calvi, D., Seveso, V. Assago e le sue cascine nel territorio milanese Parte I, Assago dalla preistoria alla dominazione austriaca. Editore Comune di Assago, 170, p. 240, 1999.

[3] Olmedo Granados, F. \& Torres Hidalgo, M. (eds.), Cortijos, haciendas y lagares. Arquitectura de las grandes explotaciones agrarias en Andalucía. Junta de Andalucía, Consejería de Obras Públicas y Vivienda, Sevilla. 510pp, 2010.

[4] Fuentes Pardo, J.M.; Cañas Guerrero, I. \& Marín Ocaña, S. The reuse of small agricultural buildings. A methodological and practical example in 'Ribera del Duero Soriana' (Central Spain). PLEA 2004, Proceedings of the 21 st Conference on Passive and Low Energy, Eindhoven, Netherlands, 2004.

[5] Fuentes, J.M., 2010. Methodological bases for documenting and reusing vernacular farm architecture. Journal of Cultural Heritage, 11(2), pp. 119-129.

[6] Plevoets, B. and Van Cleempoel, K., 2011. Adaptive reuse as a strategy towards conservation of cultural heritage: A literature review, WIT Transactions on the Built Environment, 2011, pp. 155-164.

[7] Perán, J. R et al. Renerpath: metodología de rehabilitación energética de edificios patrimoniales. Proceedings of the International Conference on Energy Efficiency in Historic Buildings, Escuela Técnica Superior de Ingenieros de Madrid, Madrid, 29-30 September, 2014.

[8] Zeren Mine, T. Adaptive re-use of monuments "restoring religious buildings with different uses". Journal of Cultural Heritage, 14(3), Supplement: Science and Technology for the Safeguard of Cultural Heritage in the Mediterranean Basin, pp. S14-S19, 2013.

[9] Ball, R. Developers, regeneration and sustainability issues in the reuse of vacant industrial buildings. Building Research and Information, 27(3), pp. 140-148, 1999.

[10] Capel Saez, H. La rehabilitación y el uso del patrimonio histórico industrial. Documents d'anàlisi geogràfica, 29, pp. 19-50, 1997.

[11] Castro Morales, F. Memoria, ocio y cultura: nuevos usos en España para el patrimonio industrial. Preservación de la Arquitectura Industrial en Iberoamérica y España, Instituto Andaluz del Patrimonio Histórico. pp. 204-212, 2001.

[12] Bullen, P.A. Adaptive reuse and sustainability of commercial buildings. Facilities, 25 (1-2), pp. 20-31, 2007.

[13] Bosia, D. Energetic behaviour and Renewable Energy in traditional rural architecture. Proceedings of the International Conference on energy management in cultural heritage in Dubrovnik. UNDP Croatia. United Nations Development Program, 2011. 
[14] Ferreira, D., et al. Bioclimatic Solutions Existing in Vernacular Architecture Rehabilitation Techniques. PORTUGAL SB13-Contribution of Sustainable Building to meet EU 20-20-20 targets. Guimarães Portugal. pp. 639-645, 2013.

[15] Hidrocerámica: Smart walls. IAAC research on temperature sensitivity and autonomous thermal conditioning of facings.

[16] Mezquita, B., Escuer, J. "Obtención de parámetros para el aprovechamiento geotérmico a partir de datos hidrogeológicos" en Libro de Actas. II Congreso de Energía Geotérmica en la Edificación y la Industria Geoener 2010.

[17] Toimil Matesanz, D., Almacenamiento de energía térmica en el subsuelo. Una tecnología prometedora para reducir el consumo de combustibles fósiles para la producción de calor. Energía: Ingeniería energética y medioambiental, Año no 37, n 230, pp. 52-57, 2011.

[18] Hendriks, M. \& Godschalk, M.S. De Pozos de refrigeración a almacenamiento de energía. I congreso de Energía Geotérmica en Edificación y la Industria - GeoEner. Madrid, España, 2008.

[19] http://solargis.info/doc/_pics/freemaps/1000px/dni/SolarGIS-Solar-mapDNI-Spain-en.png consultado 12/02/2016

[20] DIN 1989-1: 2002-04

[21] Mansergas Sellens, O. El uso del patrimonio arquitectónico. Biblio $3 W$. Revista bibliográfica de geografía y ciencias sociales. Vol. XVIII, $\mathrm{n}^{\mathrm{o}}$ 1049(11), 15 de noviembre de 2013. [On line]. Barcelona: Universidad de Barcelona, 15 de noviembre de 2013, Vol. XVIII, $\mathrm{n}^{\mathrm{o}}$ 1049(11). $<$ http://www.ub.es/geocrit/b3w-1049/b3w-1049-11.htm>. [ISSN 11389796].

[22] Bordage, F. \& Faure, F. The Factories. Conversions for Urban Culture. TransEuropeHalles. Birkhäuser-Publishers for Architecture: Basel, 2002.

[23] Tagliabue, L.C., Leonforte, F. \& Compostella, J. Renovation of an UNESCO Heritage Settlement in Southern Italy: ASHP and BIPV for a "Spread Hotel” Project. Energy Procedia, 30, pp. 1060-1068, 2012.

[24] Garzón, E.; Salinas Andujar, Jose A.; Sánchez Fernández, L. M.; Vázquez Cabrera, F. J. Los cortijos y casas señoriales de comarca del almanzora: presente y futuro. IX Congreso Internacional de Ingeniería de Proyectos, Malaga, pp. 765-771, 2005.

[25] Arcila Garrido, M. \& López Sánchez, J.A. El bosque 2010: Una propuesta de desarrollo sostenible en la finca el imperio. Investigaciones turísticas. Una perspectiva multidisciplinar: I Jornadas de Investigación en Turismo, Sevilla, 7-8 de mayo de 2008, pp. 1-26, 2008.

[26] Vos, W. \& Meekes, H. Trends in European cultural landscape development: perspectives for a sustainable future. Landscape and Urban Planning, 46(1-3), pp. 3-14, 1999. 